IZA DP No. 5430

Is Short-Time Work a Good Method to Keep Unemployment Down?

Pierre Cahuc

Stéphane Carcillo

January 2011 


\title{
Is Short-Time Work a Good Method to Keep Unemployment Down?
}

\author{
Pierre Cahuc \\ Ecole Polytechnique, \\ CREST, CEPR and IZA
}

\author{
Stéphane Carcillo \\ OECD, University Paris 1 \\ and IZA
}

\author{
Discussion Paper No. 5430 \\ January 2011
}

\author{
IZA \\ P.O. Box 7240 \\ 53072 Bonn \\ Germany \\ Phone: +49-228-3894-0 \\ Fax: +49-228-3894-180 \\ E-mail: iza@iza.org
}

\begin{abstract}
Any opinions expressed here are those of the author(s) and not those of IZA. Research published in this series may include views on policy, but the institute itself takes no institutional policy positions.

The Institute for the Study of Labor (IZA) in Bonn is a local and virtual international research center and a place of communication between science, politics and business. IZA is an independent nonprofit organization supported by Deutsche Post Foundation. The center is associated with the University of Bonn and offers a stimulating research environment through its international network, workshops and conferences, data service, project support, research visits and doctoral program. IZA engages in (i) original and internationally competitive research in all fields of labor economics, (ii) development of policy concepts, and (iii) dissemination of research results and concepts to the interested public.
\end{abstract}

IZA Discussion Papers often represent preliminary work and are circulated to encourage discussion. Citation of such a paper should account for its provisional character. A revised version may be available directly from the author. 
IZA Discussion Paper No. 5430

January 2011

\section{ABSTRACT}

\section{Is Short-Time Work a Good Method to Keep Unemployment Down?*}

Short-time work compensation aims at reducing lay-offs by allowing employers to temporarily reduce hours worked while compensating workers for the induced loss of income. These programs are now widespread in the OECD countries, notably following the 2008-2009 crisis. This paper discusses the efficiency of this type of policy and investigates its impact on unemployment and employment. There is some evidence that short-time compensation programs stabilize permanent employment and reduce unemployment during downturns. All in all, it seems that short-time work programs used in the recent downturn had significant beneficial effects. This suggests that countries which do not have short-time compensation programs could benefit from their introduction. But short-time compensation programs can also induce inefficient reductions in working hours and reduce the prospects of outsiders if used too intensively. Thus, the design of short-time compensation programs should include an experience-rating component.

JEL Classification: E24, J22, J65

Keywords: $\quad$ short-time work, unemployment, employment

Corresponding author:

Pierre Cahuc

Department of Economics

Ecole Polytechnique

91128 Palaiseau Cedex

France

E-mail: pierre.cahuc@polytechnique.edu

\footnotetext{
* This paper is commissioned for the Nordic Policy Economic Review. The authors would like to thank Lars Calmfors, Alexander Hijzen, Bertil Holmlund, Ann-Sofie Kolm, John Martin, Sebastien Martin, Stefano Scarpetta, Danielle Venn, the OECD secretariat and participants in the Nordic Policy Economic Review Conference for their help and useful comments. The opinions expressed and arguments employed here are the responsibility of the authors and do not necessarily reflect those of their corresponding institutions.
} 
Short-time compensation (or short-time work, STW) aims at reducing lay-offs by allowing employers to temporarily reduce hours worked while compensating workers for the induced loss of income. At present, short-time work schemes are widespread among OECD countries. They are operated in 25 of the 33 OECD countries. However, there are large cross-country differences in take-up rates, which go from zero to $7.4 \%$ of employees in $2009 .{ }^{1}$ Moreover, there has been a very important spread of short-time work during the 2008-2009 recession: the OECD average take-up rate was less than $0.2 \%$ in the fourth quarter of 2007 , just before the recession, and ballooned to $1.3 \%$ in the fourth quarter of 2009 .

In the recent recession, unemployment did not increase in some European countries featuring widespread and generous short-time compensation programs as much as it did in other countries. The leading example is Germany that makes a particularly intensive use of a short-time work program (the Kurzarbeit). This success induced a renewal of interest in short-time work which may appear as a good method to keep unemployment down in recessions. As a matter of fact, the interest for such schemes is not new. The idea that it could be more efficient and more equitable to share jobs with short-time compensation rather than destroying jobs during recessions is recurrently put forth by advocates of work-sharing. For instance, Abraham and Houseman (1994) argued that although the use of short-time work or the recourse to layoffs during a cyclical downturn may be reasonably close substitutes from the employer's point of view, they are quite different from the employee's perspective. Dismissed workers are likely to face considerable uncertainty about whether and when they will find a job and may experience long unemployment spells, which represent a loss of income for them and their families and a loss of resources for the society. Abraham and Houseman also argue that extensive reliance on layoffs is less equitable than work-sharing, because it concentrates the costs of adjustment on a relatively small number of workers who suffer large losses of income and other job-related benefits. Instead, short-time work arrangements spread the costs of adjustment more evenly across members of the work force. These might be important arguments in favor of short-time work to accommodate cyclical fluctuations in demand.

In this paper, we argue that optimal unemployment insurance systems may include short-time compensation programs. However, short-time compensation programs are not a panacea. They

\footnotetext{
${ }^{1}$ This refers to quarterly data, not yearly averages as shown in Figure 1. 
must be carefully designed to improve efficiency. Actually, there is some evidence that short-time compensation programs stabilize permanent employment and reduce unemployment during downturns. But short-time compensation programs can also induce inefficient reductions in working hours. Moreover, workers in permanent jobs have incentives to support such schemes in recessions in order to protect their jobs. Employers also have incentives to support short-time compensation programs in countries where stringent job protection induces high firing costs. Therefore, there is a risk to use these programs too intensively, for the benefits of insiders and at the expense of outsiders whose entry into employment can be made more even more difficult. In order to deal with this risk and to avoid inefficient reductions in working-hours, the design of short-time compensation programs should include an experience-rating component. This component would lead to a scheduling of employers' social contributions so that they bear a significant share of the cost induced by their participation in the program.

The paper is organized as follows. In section 1, we describe the evolution of short-time compensation programs in the recent recession. In section 2, we discuss the economic justifications of these programs. From a normative perspective, we begin by recalling that optimal unemployment insurance may include short-time compensation programs. Then, we analyze the existence of short-time work programs from a positive perspective to understand their potential consequences on actual labor markets of the OECD countries. Finally, in section 3 we present empirical evidence about the impact of short-time compensation program on unemployment, employment and hours.

\section{SHORT-TIME WORK ARRANGEMENTS BEFORE AND DURING THE CRISIS}

\subsection{HOW DOES IT WORK AND WHERE?}

Short-time work is an option within the unemployment insurance systems that allows employers to reduce the hours of workers for economic reasons, while permitting workers to receive compensation for their partial layoff. Compensation is usually supported by the unemployment 
insurance schemes, in the form of partial unemployment benefits, by special funds, by the State, or sometimes by a combination of these sources. ${ }^{1}$

Before the 2008-2009 crisis, short-time work schemes were already widespread in the OECD countries: ${ }^{2}$ such schemes existed in 18 countries. In 2009, they operated in 25 of the 33 OECD countries (see Figure 1), including most of the Continental European countries, and only 5 countries had no short-time work schemes. ${ }^{3}$ Among the Nordic countries, Denmark, Finland and Norway have short-time work schemes, and among the English-speaking countries Canada, Ireland, New Zealand and the US have such schemes.

Of course, the design and regulation of short-time work schemes varies greatly across countries (Hijzen and Venn, 2010). First, firms are usually required to meet a number of eligibility criteria to enter into short-time work arrangements. For instance, $80 \%$ of countries require firms to prove that economic factors make short-time work necessary (decline in production or in business activity). 55\% of countries require collective agreements, and other countries usually require either consultation with employees or individual agreements. In $40 \%$ of the reviewed countries, employees must also be eligible to unemployment benefits on an individual basis. Southern Europe countries usually set much less stringent stringent eligibility requirements than the OECD average (or than the Nordic or English-speaking countries which are close to this average). ${ }^{4}$

\footnotetext{
${ }^{1}$ Partial unemployment benefits are considered part of short-time work schemes. Part-time unemployment benefits are not. Partial benefits are paid by the unemployment insurance to employees and relate to specific employers who reduce working-time. Part-time benefits are paid to people who are unemployed but work for some time over the reference period (part-time unemployed) independently of employers, notably in countries where unemployment benefits can top-up some earned income.

2 The countries which created new schemes during the crisis (usually at the end of 2008 or the beginning of 2009) are the Czech Republic, Hungary, Mexico, the Netherlands, New Zealand, Poland and the Slovak Republic.

${ }^{3}$ Australia, the United Kingdom, Greece, Iceland and Sweden. For 4 countries, the information on STW schemes is not available (Chile, Estonia, and Slovenia).

${ }^{4}$ For the purpose of the empirical analysis in sections 1.2 and 3.3 , an eligibility index is built: its value is 0 when no criteria is requested for entry into short-time work schemes, and each additional criteria is assigned a value of either for 1 , or 0.5 for those which only apply to some categories of employees (e.g. blue-collars). 


\section{Figure 1: Short-time work take-up rates in the OECD countries}

as a percentage of employees

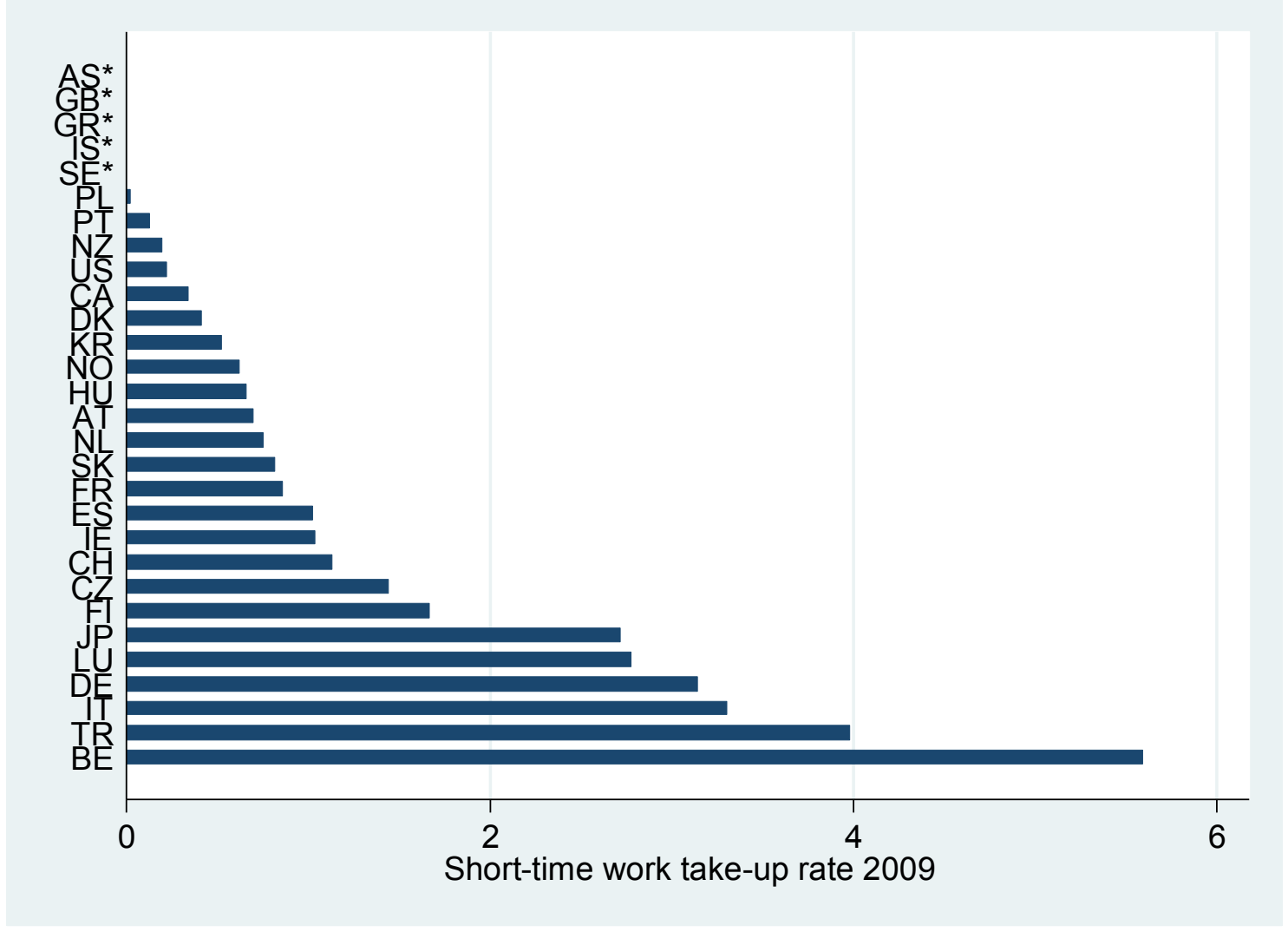

Source: OECD (2010) and Hijzen and Venn (2010) data completed by the authors

Note: * no schemes in Australia, the U.K., Greece, Iceland, and Sweden. Data are missing for Chile, Estonia, Mexico, and Slovenia. Country codes: AS: Australia; AT: Austria; BE: Belgium; CA:Canada; CH: Switzerland; CZ: Czech Republic; DE: Germany; DK: Denmark; ES: Spain; FI: Finland; FR: France; GB: United Kingdom; GR: Greece; HU: Hungary; IE: Ireland; IS: Iceland; IT: Italy; JP: Japan; KR : Korea; LU: Luxembourg; NL: Netherlands ; NO: Norway; NZ: New Zealand; PL : Poland; PT : Portugal ; SE : Sweden ; SK: Slovak Republic; TR: Turkey; US: United States. 
Short-time work schemes are also most often conditional to one (most often) or several actions to be taken by firms or employees. Those include the commitment not to dismiss employees for a certain period after the end of short-time work compensation (6 countries, half in Western Europe), job search requirements (5 countries), the design of a recovery plan (4 countries), and training of employees (4 countries). Nordic countries make short-time work compensation conditional to job search, while Asian countries (Japan and Korea) set no conditions at all like the English-speaking countries. ${ }^{1}$

Regarding the generosity of schemes, the key parameters to consider are the maximum number of hours that can be compensated per employee, the maximum duration of compensation, the net replacement rate, and the remaining cost of reduced hours (OECD, 2010, Hijzen and Venn, $2010^{2}$ ). These parameters were often modified in 2008 in countries where schemes existed before the crisis in order to make short-time work even more appealing. As such, in 2009:

- Working-time reduction can be either total or partial, depending on each schemes' rules. For instance, a $100 \%$ cut in hours can sometimes be justified when a production unit must be temporarily shut down because inventories are too high. On average, the permissible working-time reduction, i.e. the share of normal working-time that can be cut $^{3}$, is $74 \%$. For the 3 Nordic countries, the average is $63 \%$, while it is only $38 \%$ for the English-speaking countries. Half of the countries allow for reductions in hours between $90 \%$ and $100 \%$ of normal working-time, with higher rates in Eastern and Southern Europe.

- A maximum duration of compensation prevails in all countries, notably because the economic reasons that normally justify short-time work must be temporary by nature. The country average is approximately 15 months, but this parameter also varies a lot across countries, from 3 months in the Slovak Republic to 28 months in Japan (and even

\footnotetext{
${ }^{1}$ Similarly to what is done with eligibility criteria, a conditionality index is built: its value is 0 when no condition is associated with short-time compensation, and each additional condition is assigned a value of either for 1 , or 0.5 for those which only apply to some categories of employees.

${ }^{2}$ We follow here the analytical framework set ou by Hijzen and Venn, 2010. We have used the value of the parameters they identified for 2009, and we have completed these data with values for 2007 (before the crisis) for the parameters used in section 3.3.

${ }^{3}$ For instance, if in one given country the minimum working-time reduction is, say $10 \%$ and the maximum is $100 \%$, the overall permissible reduction is $90 \%$ of working time. The possibility to cut working-time by smaller amounts allows the employers to use short-time work schemes more easily and more frequently. The maximum reduction provides another obvious margin of flexibility. The permissive working-time reduction allows us to take into account these two different margins of flexibility in the use of short-time work. 
longer in Finland where the 36-month limit was removed during the crisis ${ }^{1}$ ). In the Nordic countries the maximum duration varies a lot (6 months only in Denmark, 12 months in Norway, no limit in Finland), while its average is only 9 months for the English-speaking countries. Duration is maximal among Southern Europe countries with 22 months on average.

- The net replacement rate can be calculated as the ratio of the net income of employees in the scheme to the net income that would stem from normal working time. In most countries, income falls progressively as hours fall further below their normal level. ${ }^{2}$ On average the minimum compensation rate is $71 \%$ of the full-time wage. As a comparison the full-time unemployment net replacement rate is $58 \%$ on average ${ }^{3}$ in the first month of unemployment in the same countries. In Denmark and $\mathrm{Norway}^{4}$, the average compensation rate is the highest among countries at 78\% (as a comparison, 59\% for unemployment benefits), and in English-speaking countries this rate reaches a low $62 \%$ ( $46 \%$ for unemployment benefits).

- In a majority of countries, employers bear a share of the total cost of compensation for each reduced hour. This is obviously a way to cope with moral hazard issues and to incite firms to not abuse the system. Among the 14 countries where employers contribute, the remaining cost per hour not worked ${ }^{5}$ is close to $20 \%$ of the total normal labor cost. Among the Nordic countries, Norwegian employers pay a below-average cost of $17 \%$, while their counterparts in the English-speaking countries (the US and New Zealand) bear an above-average cost of $32 \%$.

\subsection{AN OVERVIEW OF TAKE-UP BEFORE AND DURING THE CRISIS.}

Even in the context of the exceptional downturn that most of the OECD economies experienced in 2008 and 2009, the recourse to short-time work varies a lot across countries. Take-up can be measured as the ratio of short-time work participants to the total number of employees in a given

\footnotetext{
${ }^{1}$ However, a maximum payment period of 500 full-time equivalent working days remains.

${ }^{2}$ In Hungary and Korea however, workers receive their full wage for all reduced hours (Hijzen and Venn, 2010)

${ }^{3}$ For a single worker with no children earning the average wage. The data come from the OECD taxes and benefits database.

${ }^{4}$ This information is not available for Finland.

${ }^{5}$ For a single worker with no children earning the average wage. 
country. ${ }^{1}$ In 2009, six countries where short-time work existed prior to the crisis stand out with take-up rates above $2 \%$ of employees: Belgium, Turkey, Italy, Germany, Luxembourg and Japan (see Figure 1).

At the other end of the scale, the countries of Northern Europe (except Finland) either show low take-up rates (such as Denmark and Norway, below 1\%), or no short-time work scheme at all (such as Iceland and Sweden). The English-speaking countries (except Ireland) show a similar pattern (take-up below 0.5\% in Canada, New Zealand and the U.S., no scheme in Australia and the U.K.).

In most countries where schemes existed prior to the crisis, participation in short-time work arrangements has dramatically increased since the last quarter of 2008, or at the beginning of 2009, to reach unprecedented levels (except in Norway and Belgium where levels were similar or close to the levels in 2003, see Figure 2, and in Germany, where take-up rates were very high in 1993 - not shown).

The magnitude of the recession is of course one of the determinants of the recourse to shorttime work. A high take-up of short-time work on average in 2009 is usually associated with a strong decline in industrial production measured between end-2008 and end-2009 (see Figure 3, using the OECD industrial production index). Interestingly, countries with high take-up rates in 2009 are also those where the production index recovered significantly over the same year. This can be interpreted in various ways, one rationale being that countries where the decline in industrial production was the largest at the end of 2008 were also those where the expected rebound would be the largest in 2009 (once inventories have reached a bottom); another explanation is that in those countries the labor force in the industry was maintained during the crisis, allowing firms to react more quickly to the upturn.

Cross-country institutional differences in short-time work schemes are also related to the dispersion of take-up across countries. Actually, take-up rates do not appear to be related to the stringency of conditions required to benefit from short-time compensation (commitment to not dismiss employees for a certain period after the end of short-time work compensation, job search requirements, the design of a recovery plan, training of employees). The correlation coefficient between our conditionality index, and the take-up rate is zero in 2009. It might be that these

\footnotetext{
${ }^{1}$ This ratio is rather a pseudo take-up rate, since all employees are not necessarily eligible to short-time work schemes, depending on the eligibility conditions set in each country. 
conditions do not play an important role because they are difficult to enforce in several countries. ${ }^{1}$

1 A more sophisticated index including different weight for each specific component could yield different results; but the choice of weights would be arbitrary. 
Figure 2: Short-time work take-up rates in the OECD countries 2003-2010 as a percentage

of employees. STW : Short-time work take-up rate. Source : OECD (2010) and Hijzen and Venn (2010) data completed by the authors.
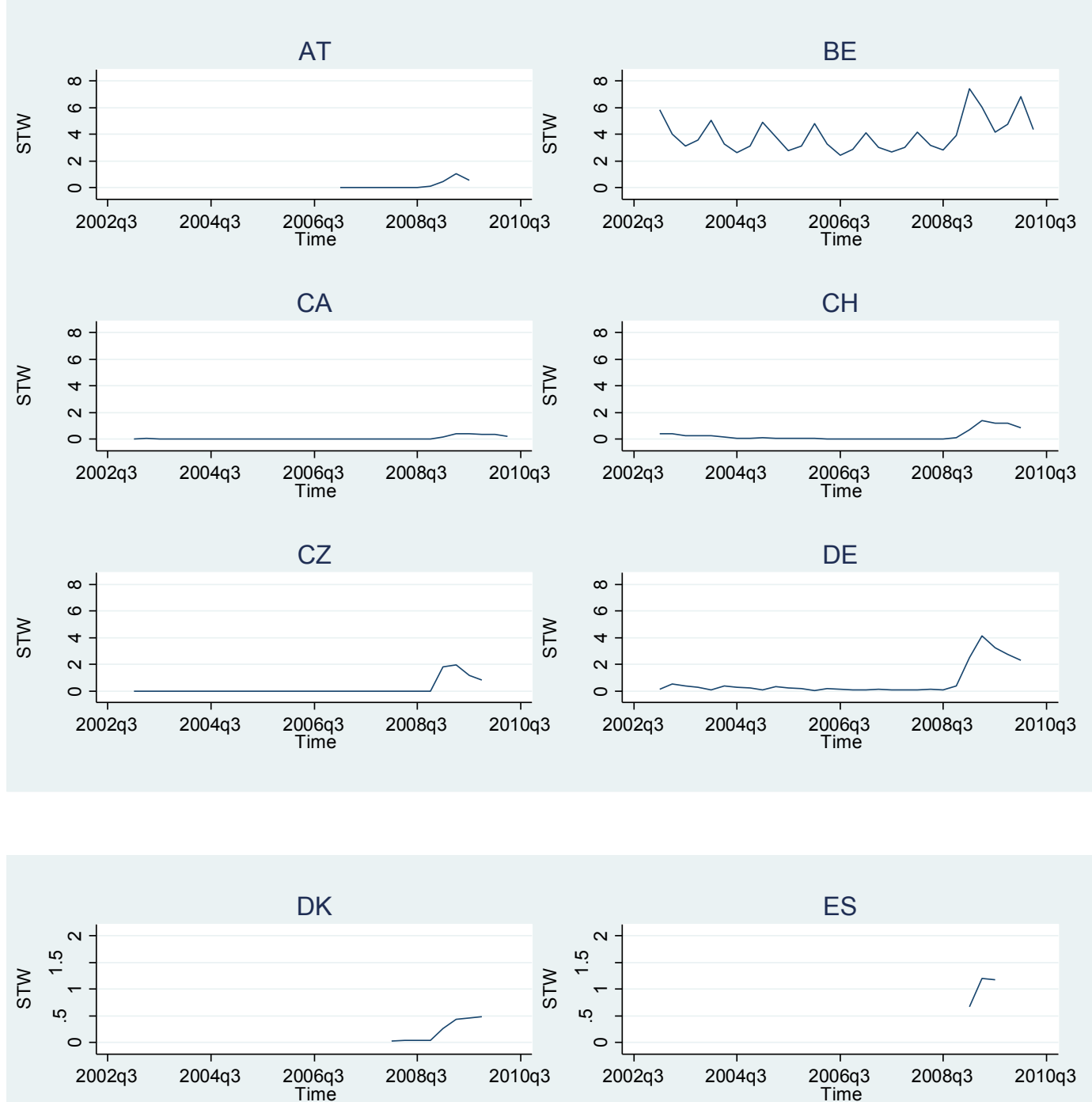

$\mathrm{FI}$

FR
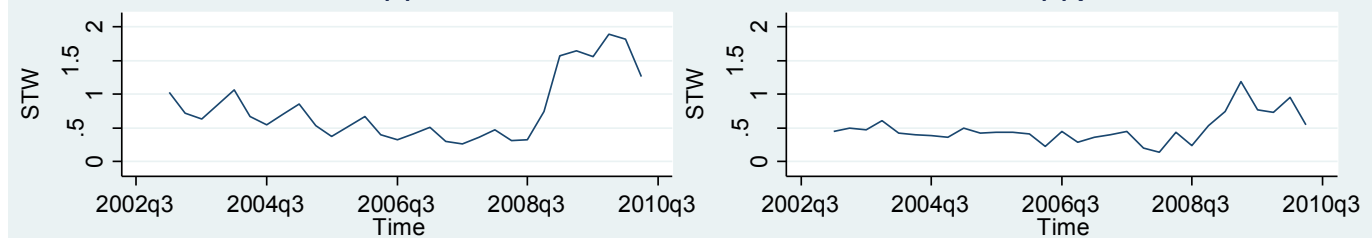

HU

IE
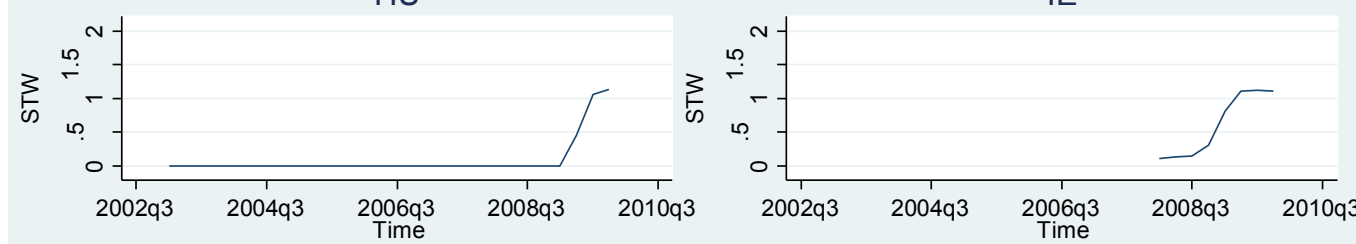
Figure 2 (cont'd): Short-time work take-up rates in the OECD countries 2003-2010

as a percentage of employees. STW : Short-time work take-up rate. Source : OECD (2010) / Hijzen and Venn (2010) completed by the authors.
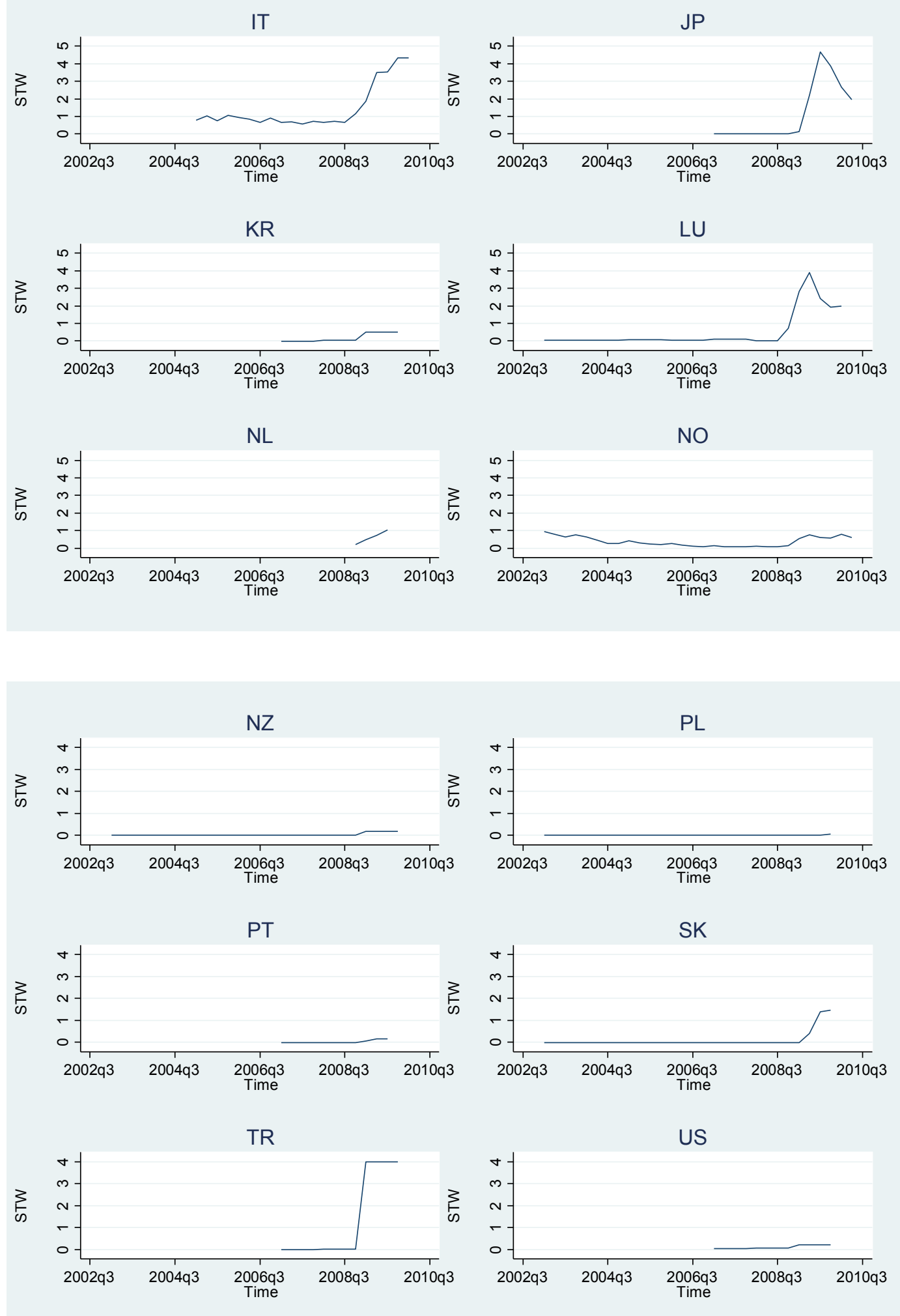
However, there is a positive correlation, equal to $31 \%$ in $2009^{1}$, between the take-up rate and the eligibility criteria to enter into short-time work arrangements (including requirements to prove that economic factors make short-time work necessary, requirement of collective agreements, requirement of consultation of employees or of individual agreements, eligibility to unemployment benefits). Countries with large take-up rates tend also to have more sophisticated eligibility systems. Other parameters of short-time schemes are also clearly correlated with takeup (at least in 2009). The correlation between the take-up rate and the permissible reductions in weekly working hours that can be compensated amounts to $43 \%$. For instance, countries with high take-up authorize reductions in hours of at least $50 \%$ or more of normal working-time (see Figure 4). The correlation between the take-up rate and the maximum duration of the scheme, expressed in months, is 28\% (see Figure 5). Similarly, in most countries where take-up is highest, the remaining cost of reduced hours for employers is actually 0 or less than $10 \%$ of the normal total cost (See Figure 6).

Figure 3: Industrial production index and short-time work take-up rate in 2008-2009

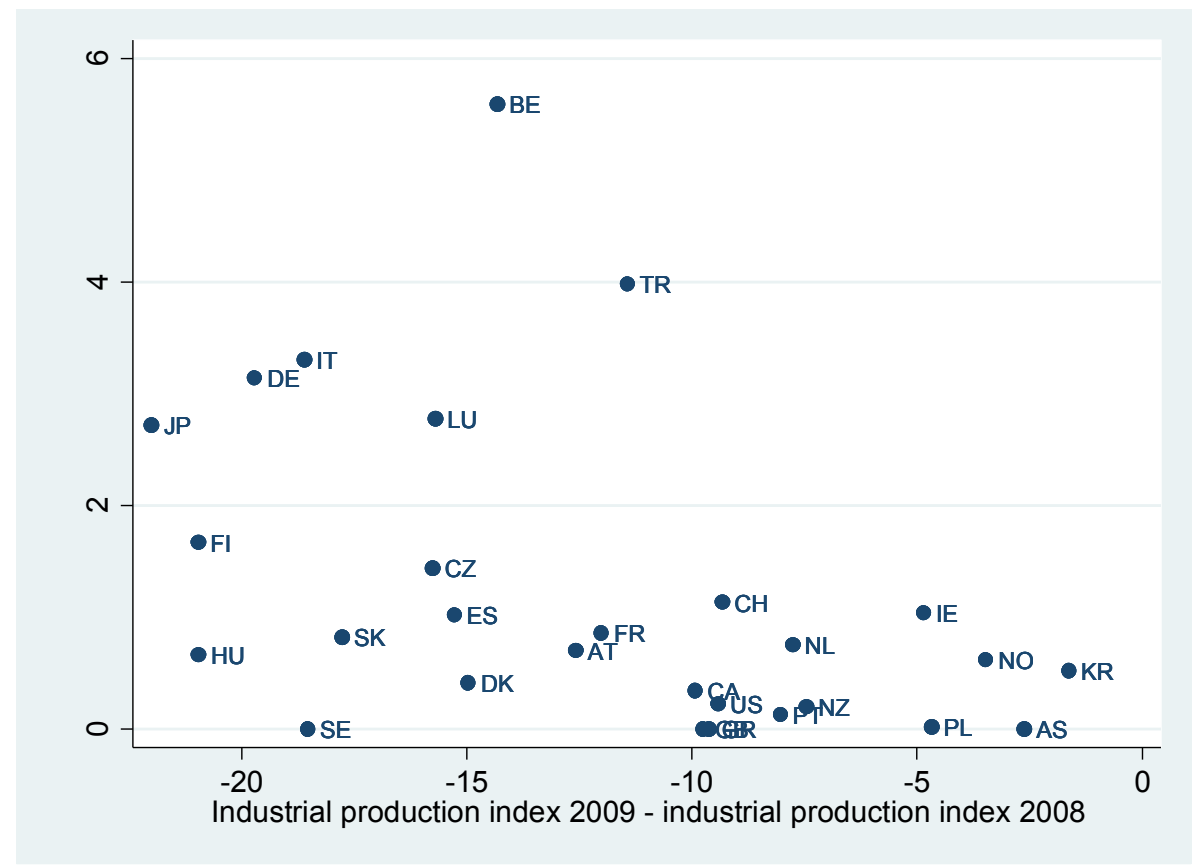

Source: OECD (2010) and Hijzen and Venn (2010) data completed by the authors, OECD industrial production index

\footnotetext{
${ }^{1}$ Here and in what follows, a correlation refers to the simple correlation coefficient between two variables, not to the regression coefficient i.e. the slope of the lines shown in the scatter Figures. 
Figure 4: Permissible reductions in weekly working hours and short-time work take-up rate $^{1}$

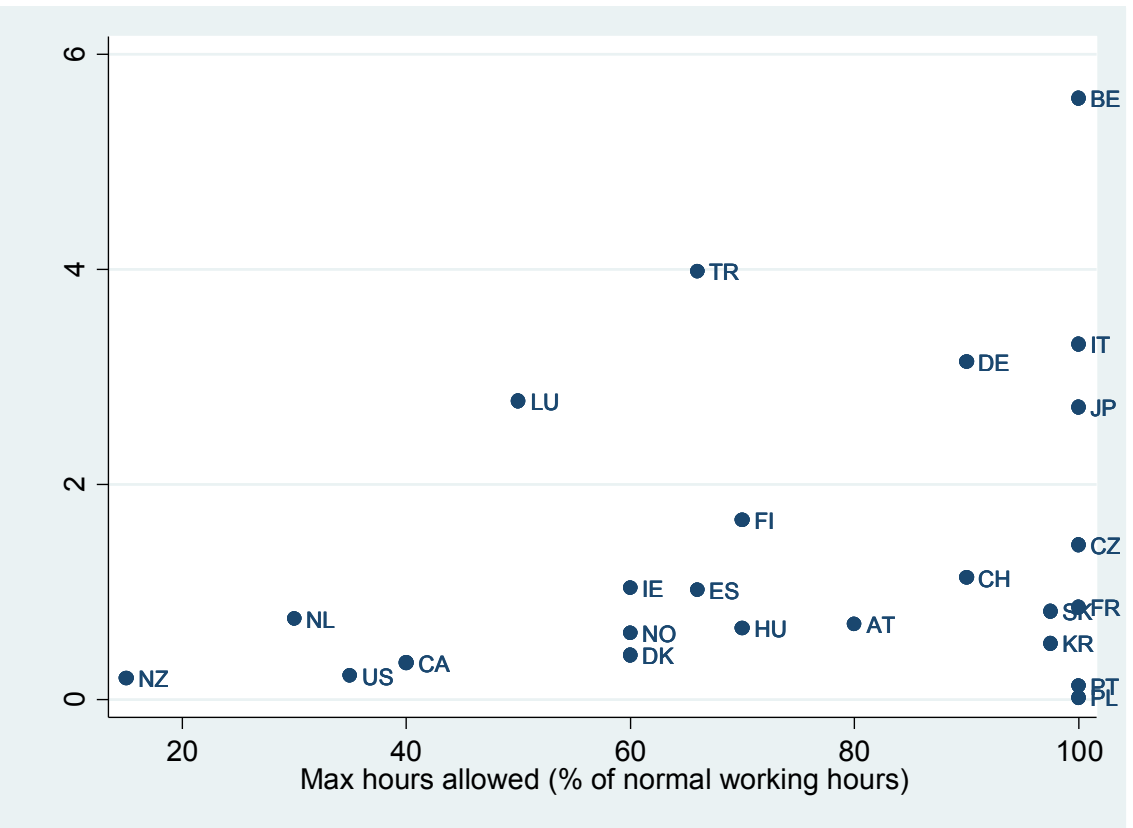

Source: OECD (2010) and Hijzen and Venn (2010) data completed by the authors

Figure 5 : Maximum duration of scheme participation and short-time work take-up rate

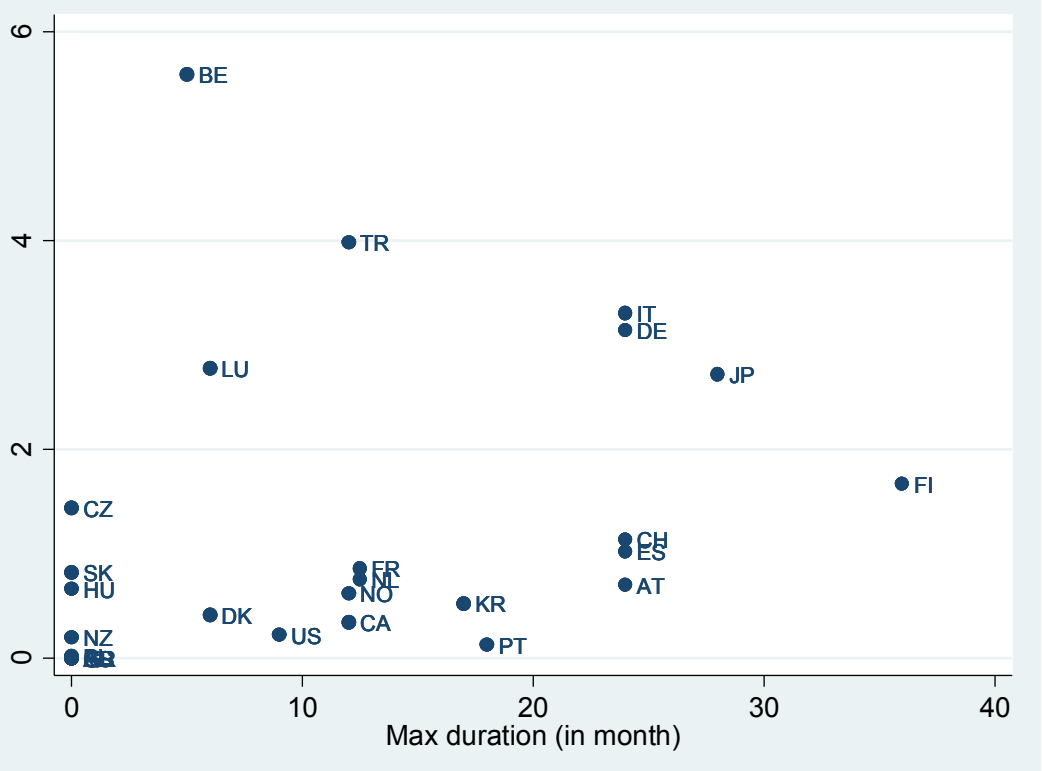

Source: OECD (2010) and Hijzen and Venn (2010) data completed by the authors

\footnotetext{
${ }^{1}$ Permissible reductions in weekly working hours are the shares of normal working time that can be reduced within STW schemes. 
Figure 6 : Average remaining cost for employers and short-time work take-up rate

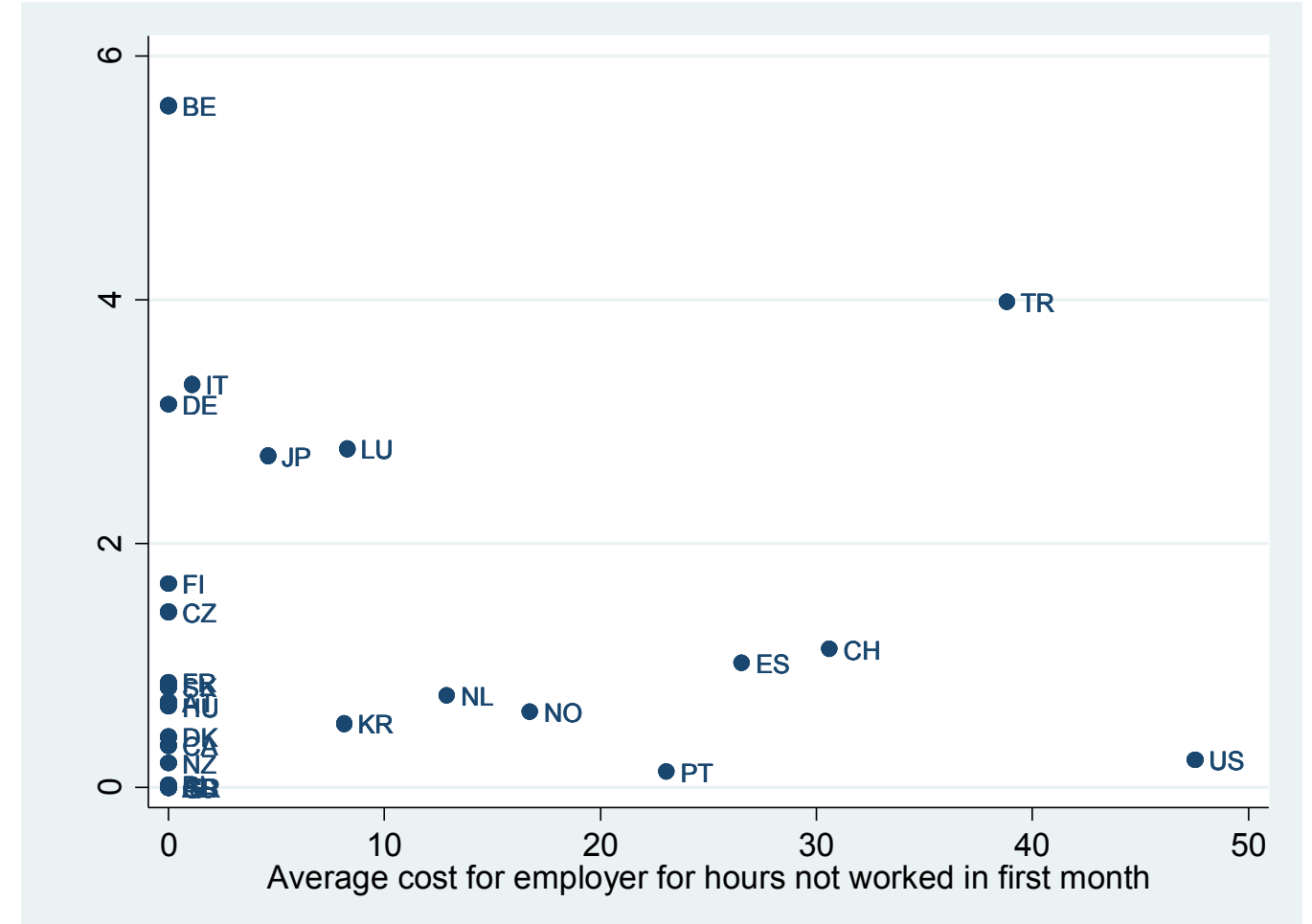

Source: OECD (2010) and Hijzen and Venn (2010) data completed by the authors

\section{THE CONSEQUENCES OF SHORT-TIME WORK: THEORY}

Short-time work can be justified from the point of view of the unemployment insurance system. It turns out that it can be efficient to combine short-time compensation provided to short-time unemployed workers with unemployment benefits provided to full-time unemployed workers. However, the existence of short-time work observed in OECD countries does not necessarily rely only on efficiency considerations. The spread of short-time work can also be influenced by insiders supporting part-time work in order to try to protect their jobs in deep recessions. This implies that part-time work arrangements may potentially protect the jobs of some categories of workers at the expenses of others. 


\subsection{OPTIMAL UNEMPLOYMENT INSURANCE AND SHORT-TIME WORK}

The analysis of optimal labor contracts shows that optimal insurance can comprise layoffs and short-time work schemes (Rosen, 1985). The precise form of the insurance contract hinges on the preferences of workers and on the technology of firms. For instance, Rosen (1985) and Fitzroy and Hart (1985) have developed models where the (monthly) wage is flexible and hours of work adjust when productivity is above a certain threshold, while the (monthly) wage is downward rigid and layoffs are used instead when productivity is below this threshold. ${ }^{1}$ In such a model, it can be optimal to include work-sharing schemes in unemployment insurance. However, this analysis assumes that insurance is directly provided by risk-neutral employers, having access to perfect financial markets. Actually, in most countries workers are covered by public unemployment insurance systems which face moral hazard issues stemming from the behavior of employers and employees.

From this perspective, the introduction of short-time work arrangements in unemployment insurance is often seen as a means to avoid excess layoffs (e.g. Fitzroy and Hart, 1985, Burdett and Wright, 1989). ${ }^{2}$ In the presence of an unemployment insurance which provides unemployment benefits to full-time unemployed workers only, it is well known that there are excess layoffs if employers have no incentives to internalize the social cost of their decisions. Feldstein (1976), and more recently Blanchard and Tirole (2007) as well as Cahuc and Zylberberg (2008), claimed that experience-rating systems, where employers' social contributions depend on the induced social cost of their firing decisions, can be used to reduce excess layoffs. These layoffs can be completely eliminated when there is full experience-rating, i.e. when each firm fully covers the induced social cost of its firing decisions. However, there are limits to experience-rating. ${ }^{3}$ Notably, many firms - especially small ones which have a limited access to financial markets may face financial constraints in the short-run and go bankrupt if they have to cover the social costs of their layoffs. For these reasons, full experience-rating is unlikely to be optimal and unemployment insurance is necessarily plagued with excess layoffs. In these circumstances, a

\footnotetext{
${ }^{1}$ In their framework, the production technology is multiplicatively separable between hours and workers, and there is no income effect on labor supply.

2 Although there is a quite abundant literature on optimal unemployment insurance, there are only a few recent papers about the optimality of short-time work schemes. Most recent research about optimal unemployment insurance focused on the optimal level of unemployment benefits, their time profile during the unemployment spell, the impact of sanctions, the consequences of monitoring (Fredriksson and Holmlund, 2006) and the desirability of experience-rating (Blanchard and Tirole, 2009). In most recent papers, hours are not taken into account. Workers can either work or be unemployed.

${ }^{3}$ See Blanchard and Tirole (2007) for a discussion. 
system combining short-time work arrangements with unemployment benefits seems more equitable and efficient than unemployment benefits only. This system can be more efficient because it reduces excess lay-offs encouraged by the implicit subsidies paid out by the public unemployment insurance. It is also more equitable because short-time schemes distribute the adjustment burden over a large number of workers (Abraham and Houseman, 1994, Walsh et al., 1997; Vroman and Brusentev, 2009).

However, Burdett and Wright (1989) claimed that short-time work is not a panacea. In fact, the same problem which plagues unemployment insurance, i.e. excess lay-offs in the case of partially experience-rated systems, also creates distortions under short-time work arrangements. Shorttime schemes implemented by unemployment insurance can bias downwards the average number of hours worked because they subsidize reductions in working time. Accordingly, they induce inefficient reductions in working-time in the absence of incentive schemes that would limit their recourse. An experience-rating system, where employers and employees reimburse the cost due to their utilization of short-time work, may provide adequate incentives ${ }^{1}$. Unfortunately, as mentioned above, full experience-rating is generally not efficient when firms have access to imperfect financial markets, and excess short-time cannot be fully eliminated ${ }^{2}$.

Finally, the analysis of unemployment insurance in a second-best environment featuring imperfect financial markets suggests that an efficient system should combine unemployment benefits given to unemployed workers, short-time work schemes and experience-rating which implies that social contributions paid by employers to finance unemployment insurance depend on the costs induced by their layoffs and by their utilization of short-time work schemes. The precise optimal combination of these different elements depends on the preferences of workers, on the technology of firms and on the functioning of markets. This might explain the strong cross-country heterogeneity in the implementation of short-time work schemes described in the previous section. For instance, it might be true that countries in which workers have a strong aversion for geographic mobility, because they have strong family ties (Alesina et al., 2010) or strong local ties (Janiack and Wasmer, 2010), favor adjustments of hours of work and income at the expense of layoffs. In countries where commuting costs and imperfections of the housing

\footnotetext{
${ }^{1}$ Other strategies of limitations to STW recourse have been implemented by some countries instead, such as a share of the benefits directly borne by employers, or the commitment not to lay off workers for some time after the shorttime work period has ended.

${ }^{2}$ In practice, experience-rating has been implemented in the United States only, including for temporary layoffs. See Burdett and Wright (1989). The fact that no other country has implemented this system yet can stem from political economy (winners, losers) or practical considerations (potential complexity) rather than because the system might not be fully efficient. 
markets induce a decline in geographical mobility, workers and employers might also display the same preference.

\subsection{INTERACTIONS WITH OTHER REGULATIONS AND POLITICAL ECONOMY ISSUES}

Most countries where it is more difficult to lay off workers have also designed institutional mechanisms to make these discharges less necessary. Short-time work schemesare one such measure. When layoffs are costly, employers have incentives to support short-time schemes which allow them to save on firing costs. Short-time work arrangements are also supported by insiders, who may prefer part-time unemployment combine with some work income to full time unemployment.

As claimed by the OECD (2010, chap 1), there is some evidence of a cross-country trade-off in regulations affecting internal and external flexibility. Short-time work schemes also tend to be more developed in countries with stricter employment protection rules, notably Belgium, Germany, Italy, Luxemburg and Turkey. This is apparent on Figure 7, which displays the relation between short-time work rates in 2009 and the OECD's overall strictness of employment protection index. There is a positive correlation between the stringency of employment protection and short-time work take-up rates. The correlation coefficient between quarterly short-time-work rates and the OECD overall employment protection index over the period $2007-2009$ is equal to $22 \%$.

Figure 7: Employment protection indexes and short-time work take-up rate
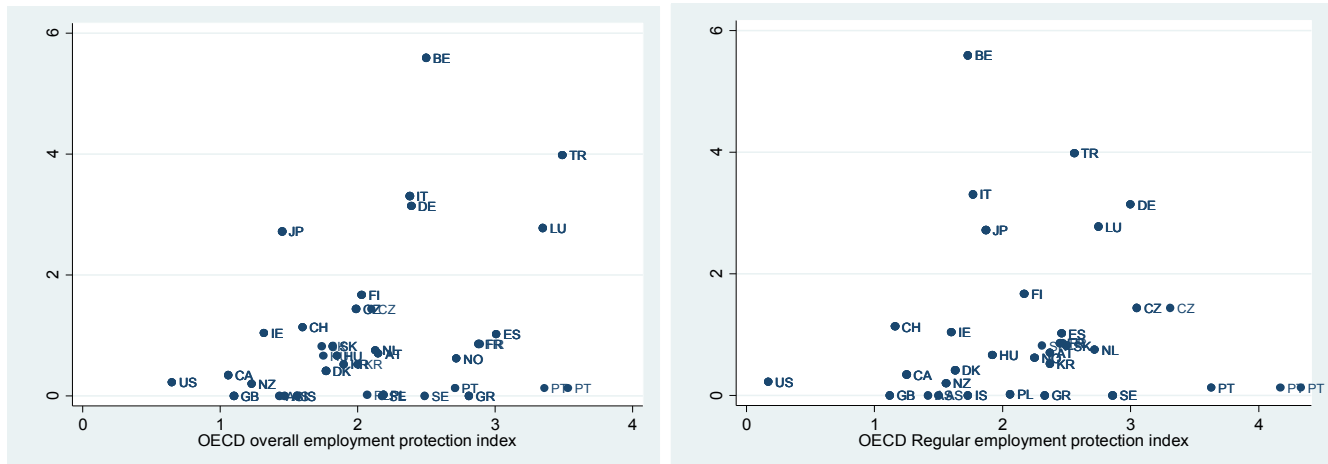

Source: OECD (2010) and Hijzen and Venn (2010) data completed by the authors, OECD's Employment protection index 
One may also expect a relation between short-time work rates and unemployment benefits. This relation can rely on different mechanisms. To the extent that short-time work schemes generally constitute a part of unemployment insurance, more generous unemployment insurance systems can have higher unemployment benefits and more generous short-time work arrangements. However, the relation between short-time work rates and unemployment benefits is also the consequence of a trade-off between short-time compensation and unemployment benefits. Figure 8 displays the relation between unemployment benefits replacement rates and short-time work rates in the OECD countries in 2009. The correlation coefficient between quarterly shorttime work rates and unemployment benefits replacement rates for OECD countries over the period 2007-2009 is positive but small, and equal to 11 percent.

Figure 8: Unemployment benefits net replacement rate and short-time work take-up rate

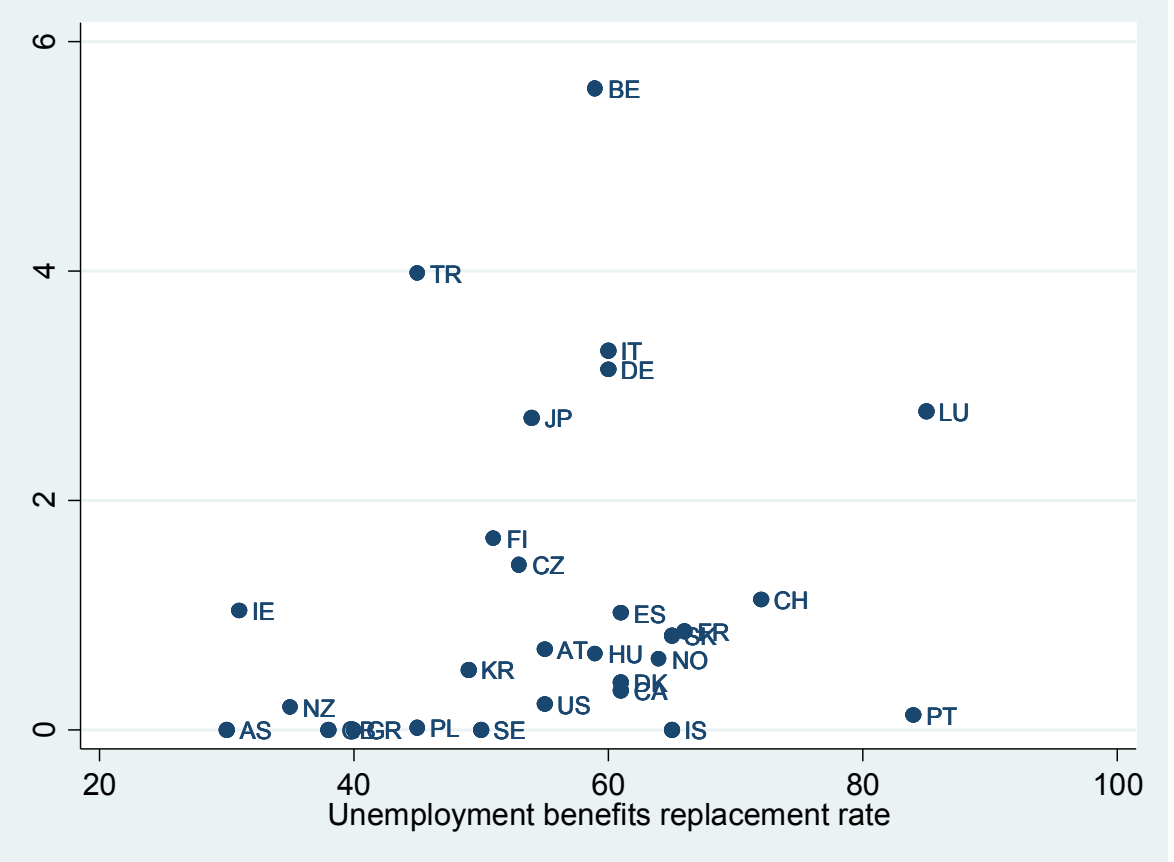

Source: OECD (2010) and Hijzen and Venn (2010) data completed by the authors, OECD tax and benefits database.

The positive relations between short-time work schemes on one hand and unemployment benefits and job protection on the other hand suggest that cross-country differences in shorttime work schemes do not only reflect efficiency considerations. They might also reflect differences in the power of insiders. This implies that short-time schemes are not necessarily beneficial to all workers. They may benefit insiders, but not outsiders who may suffer from shorttime work. 


\section{EMPIRICAL EVIDENCE}

In this section, we analyze the effects of short-time work on hours, employment and unemployment. We first provide a brief survey of the literature. Then, we present empirical evidence on the consequences of short-time work in the recent recession using cross-country data over the period 2003-2009.

\subsection{FIRM-LEVEL STUDIES}

Some studies use firm-level data to explore the impact of short-time work schemes on various outcomes, including employment. Calavrezo et al. (2009a, b) assess the impact of short-time work arrangements in France on layoffs and firm survival. Surprisingly, they find that short-time work is associated with more layoffs and lower survival of firms. This may indicate a selection bias problem due to the fact that participating firms tend to be less competitive than other firms. If this selection problem is not adequately addressed, it may be falsely concluded that short-time compensation programs result in more layoffs and more destructions of firms.

There are also several studies focused on Kurzarbeit, the well-known and long-standing STW program in Germany. Deeke (2005) showed that a high proportion of firms using Kurzarbeit did not reduce their payrolls and hire new staff with more flexible nonstandard work contracts such as "Mini-Jobs". In fact, companies employing workers with flexible work contracts (e.g. temporary and part-time contract, freelancer) rely less on short-time schemes, which suggests that short-time schemes are a way to enhance internal flexibility, especially when employment protection legislation is stringent.

The report of Berkeley Planning Associates \& Mathematica Policy Research, Inc. (1997) reviews short-time compensation programs in the United States. When the report was released, 17 states operated short-time compensation programs, 36 states and jurisdictions did not. These programs were implemented between the late 1970s and the mid 1990s. The report does not yield clear-cut conclusions about the impact of short-time compensation schemes on unemployment insurance systems and on layoffs. This report also mentions that the extensive repeat use of short-time compensation and the greater economic distress among short-time compensation firms than non- short-time compensation firms, should deserve further investigation to deal with the selection bias problem which plagues the results of empirical work relying on firm-level data. 


\subsection{COUNTRY LEVEL AND INDUSTRY LEVEL STUDIES}

The contribution of Abraham and Houseman (1994) was the first study to yield systematic crosscountry evidence about the consequences of short-time schemes. Abraham and Houseman were challenging the idea that job security regulations which became more stringent in European countries in the 1970s and in the 1980s, were significantly slowing down the adjustment of total hours of work to an unexpected shock. They argued that strong job security regulations have typically been accompanied by measures intending to facilitate alternatives to layoff such as worksharing. Abraham and Houseman wanted to understand whether and to what extent variations in working hours offered employers a viable substitute to adjustment through layoffs. For this purpose, they compare aggregate adjustment patterns in employment and hours worked across countries and over time using quarterly time-series data for Belgium, France, Germany and the United States. They find that the adjustment of employment to changes in output is much slower in the German, French and Belgian manufacturing sectors than in the United States manufacturing sector, even though the adjustment of total hours worked (i.e. hours times employment) appears to be similar in the former countries. The adjustment of weekly hours is faster in Belgium, France and Germany where short-time compensation programs operate.

Van Audenrode (1994) analyzes the adjustment of hours and employment in 10 OCED countries over the period 1969-1988. He finds that five countries display comparably fast adjustments in total hours: the United States, Belgium, Denmark, Italy, and Sweden. In the four European countries, this quick adjustment in total hours happens despite much slower employment adjustments than in the United States. Van Audenrode argues that there are more generous short-time systems in these European countries than in the United States. ${ }^{1}$ Therefore, he concludes that generous short-time compensation programs result in flexible work and foster fast adjustment in total hours despite restrictions on firings. He also argues that working-time is not flexible enough to compensate for the slower employment adjustments generated by the restrictions on firings in the countries with less generous or with no short-time compensation programs. ${ }^{2}$ Van Audenrode finds that the overall labor adjustments end up being as flexible as in the United States in countries with strong job protection because working-time adjustments compensate for restrictions on firings.

\footnotetext{
${ }^{1}$ Note that Sweden does not have any government-support system for short-time work.

${ }^{2}$ Japan behaves differently than the other countries in the sample. Despite having few formal restrictions on firings, employment adjusts very slowly. This observation corresponds to the traditional image of a large share of Japanese labor market providing lifetime jobs. However, despite having generous short-time compensation programs, Japan does not seem to have fast adjustment of hours either. One possible explanation could be that the margin of adjustment is more often earnings than hours (via the fluctuations in bonuses). 
The two previous studies of Abraham and Houseman (1994) and Van Audenrode (1994) give some evidence on the consequences of short-time work schemes before the 1990s. After the publication of these two studies, short-time work schemes did not catch much attention among economists. However, the strong increase in short-time work during the recent recession has sparked off a renewal of interest.

The recent paper by Hijzen and Venn (2010) from the OECD, exploits the cross-country and time variation in take-up rates to analyze the quantitative impacts of short-time compensation programs on employment and average hours in the 2008-09 recession. Their analysis is based on quarterly data for the period 2003-2009 for 19 countries OECD countries and four industries (manufacturing, construction, distribution and business services). It also distinguishes between permanent workers and temporary workers. Among the 19 countries, 11 countries operated a short-time compensation scheme during the entire period, five countries introduced a new scheme during the crisis period and three countries never had a short-time compensation scheme during the sample period. The impact of short-time compensation programs is estimated with an interaction term between a dummy signalling the 2008-2009 recession and another variable measuring the extent of short-time compensation programs in each country. The estimates support the conclusion that short-time compensation programs had an important impact on preserving permanent jobs during the economic downturn, with the largest proportional impacts in Japan and Germany. Using the baseline estimates, it is found that 0.7 to $0.8 \%$ of jobs were saved in Germany and Japan, respectively. Their estimates suggest that STW had no significant impact on either the employment or average hours of temporary workers.

Similarly, Arpai et al. (2010) evaluate the impact of short-time compensation programs in the 2008-2009 recession with data covering 27 European Countries over the period 1991Q2-2009Q3. The dependent variable is the annualized change in employment in the manufacturing sector. The impact of short-time compensation programs is estimated with an interaction term between a dummy signalling the 2008-2009 recession and another dummy signalling countries with shorttime compensation programs. Country fixed effects are also included. The findings confirm those obtained by Hijzen and Venn (2010): the value of the coefficient associated with the interaction term is positive and significant.

This short overview shows that empirical research suggests that short-time work arrangements reduce the volatility of employment and increase the adjustment of hours. However, our knowledge is still very limited. Empirical studies are weakened by important selection biases and endogeneity issues. Studies which rely on firm-level data have difficulties to deal with the 22 
selection bias due to the fact that participating firms tend to be less competitive than other firms. In studies relying on cross-country data, the issue of the endogeneity of short-time compensation programs is not addressed. Yet, the recent recession shows that governments and social partners improved access to short-time work schemes when unemployment increased, in order to try to limit job destructions.

\subsection{THE IMPACT OF SHORT-TIME WORK IN THE RECENT RECESSION}

We now analyze the consequences of short-time work programs on unemployment and employment in the recent recession. To deal with this issue, we use the OECD (2010) quarterly database on short-time work take-up rates, which is updated to include a larger number of countries (up to 25). Unemployment and employment quarterly data are from the OECD harmonized labor market database, which is built from national Labor force surveys (no seasonal adjustment).

To evaluate the relation between short-time compensation programs and unemployment, we estimate the following model:

$u_{c t}=\alpha_{0}+\alpha_{1} D_{t}+\alpha_{2} S T W_{c t}+\alpha_{3} X_{c} \times D_{t}+\eta_{c}+\varepsilon_{c t}$

where $u_{c t}$ denotes the unemployment rate of country $c$ at date $t . D_{t}$ is a dummy variable which takes the value 1 from the date of entry of the world economy into the recession (the first quarter of 2008) and which is 0 before this date. $S T W_{c t}$ is the short-time work take-up rate in country $c$ at date $t . X_{c}$ is a vector of time invariant controls, which comprises indicators of employment protection legislation and of the generosity of unemployment benefits proxied by the net replacement ratio. $\eta_{c}$ is a country fixed effect which includes all the time invariant characteristics, like the degree of coordination of wage bargaining for instance. $\varepsilon_{c t}$ is an error term.

\footnotetext{
${ }^{1}$ To the extent that there are very little changes in the employment protection legislation indexes and in the replacement ratios, we consider only the average of these variables over the period 2007-2009. This strategy has the advantage to avoid to deal with the potential endogeneity of these policies during the recession. Indeed, it is possible that strong increases in unemployment induce government to change these policies. For the same reason, we do not include active labor market policies in the regressions. It is also possible to introduce an interaction between the short-time work take-up rate and the time dummy. However, since the short-time work take up rate is either equal to zero or very close to zero before the recession in most countries, as shown by Figure 2, there are not enough observations to estimate the coefficient associated with such an interaction term. 
This set-up allows us to take into account the impact of a common macroeconomic shock from the beginning of the recession. The interaction term between the dummy variable $D_{t}$, which represents the shock, and the controls $X_{c}$ implies that the impact of the shock can be different across countries, as in Blanchard and Wolfers (2000). Moreover, our set-up includes country fixed effects which account for time invariant unobserved variables that could influence the unemployment rate.

Let us denote by $\Delta x_{t}$ the difference between $x$ at date $t$ and its average over the year 2007. Then, the equation above can be written as

$$
\Delta u_{c t}=\alpha_{1}+\alpha_{2} \Delta S T W_{c t}+\alpha_{3} X_{c}+\Delta \varepsilon_{c t}
$$

This equation estimates the relation between changes in the unemployment rate and changes in the short-time work take-up rate.

Figure 9: The cross-country relation between changes in unemployment rates and changes in short-time work take-up rate in years 2009-2007.

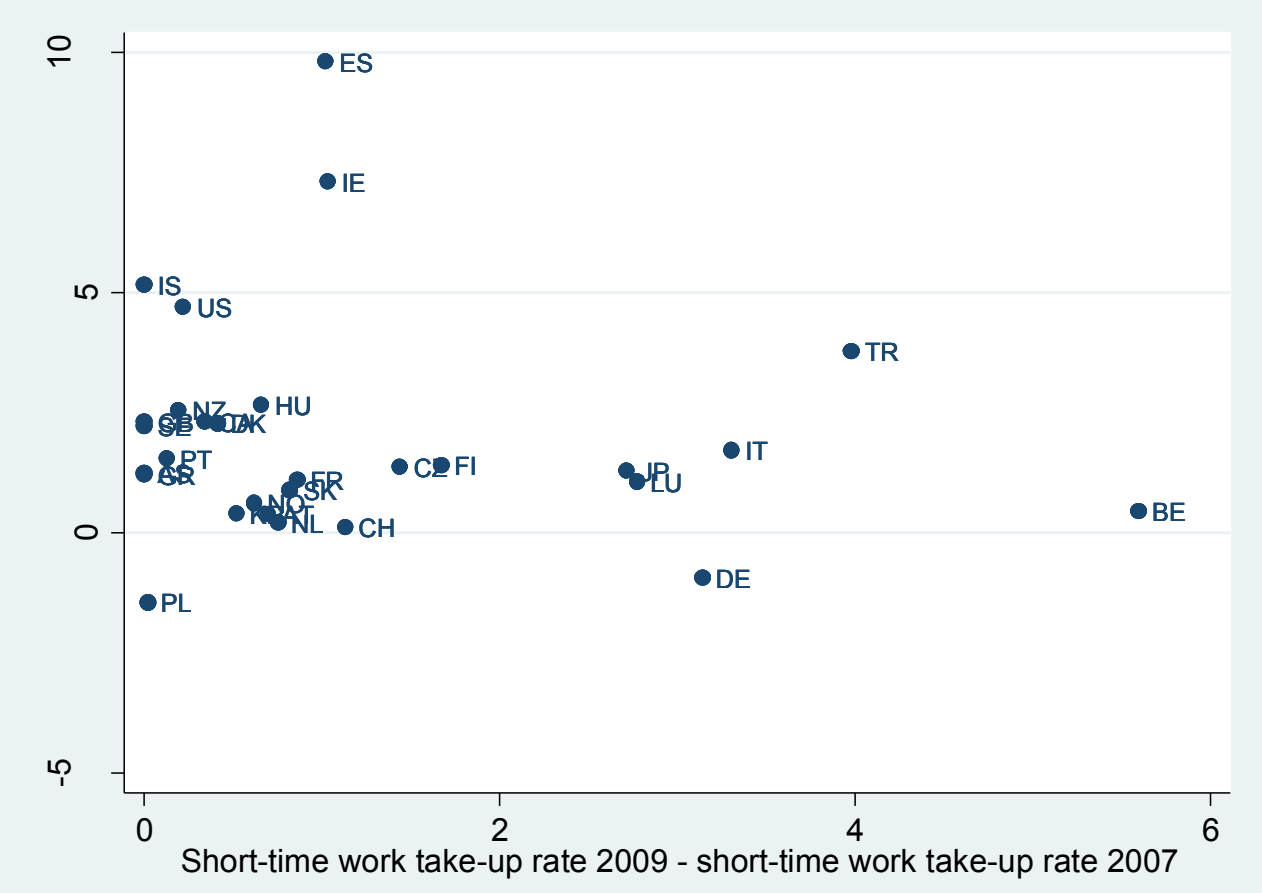

Source: OECD (2010) database, updated by the authors.

Reading: In Belgium, the unemployment rate increased by 0.2 percentage points from 2007 to 2009 (yearly averages) and the short-time work take-up rate increased by 5.8 percentage points over the same period. 
Figure 10: The cross-country relation between changes in employment rates and changes in short-time work take-up rate in years 2009-2007.

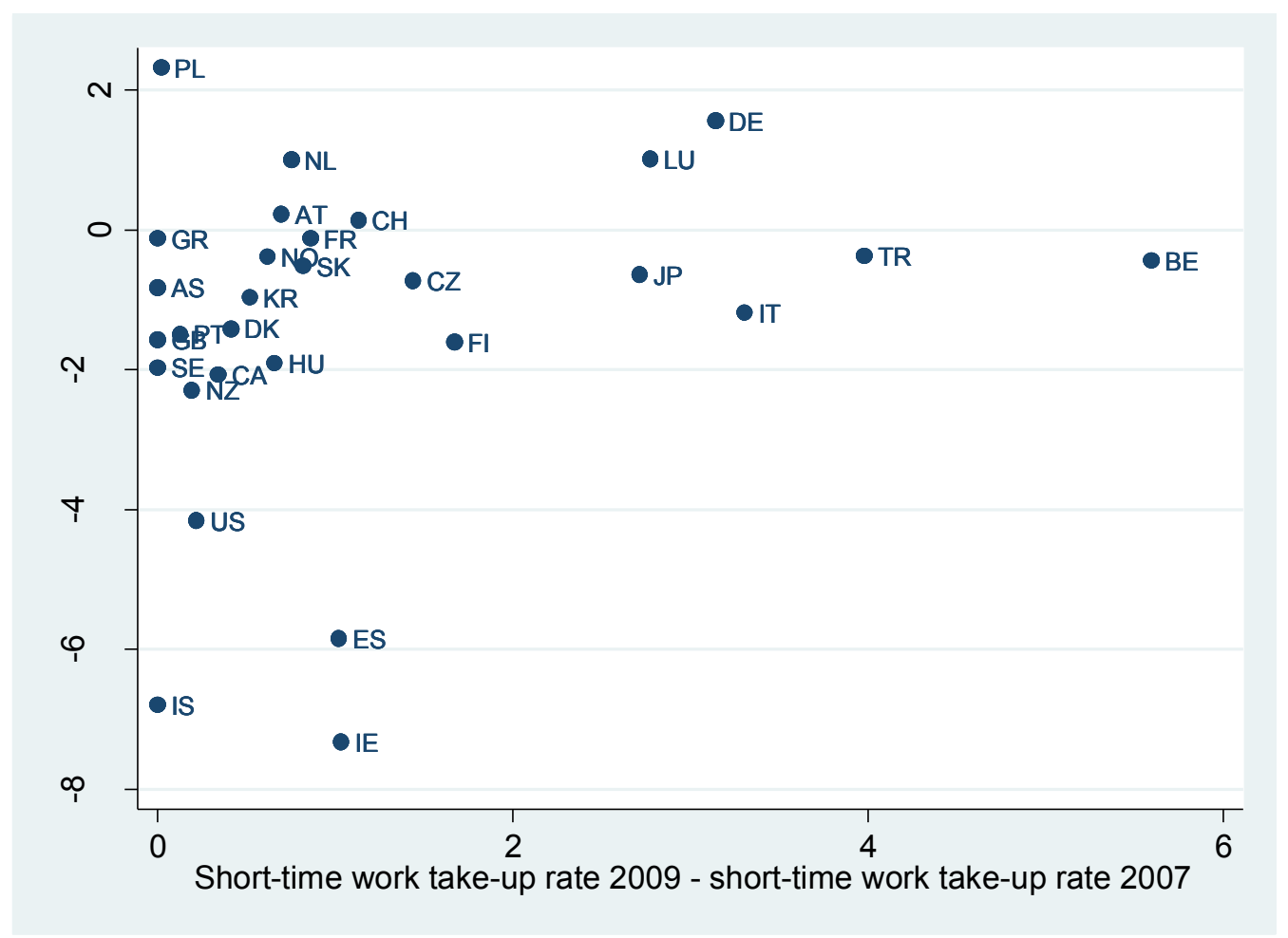

Source: OECD (2010) database, updated by the authors.

Reading: In Belgium, the employment rate increased by 0.3 percentage points from 2007 to 2009 (yearly averages) and the short-time work take-up rate increased by 5.8 percentage points over the same period.

The relation between changes in unemployment rates and changes in short-time work take-up rates between 2007 and 2009 is displayed on Figure 9. At first sight, there is a slightly negative relationship between these two variables. Some countries, like Germany and Belgium, experienced higher increases in take-up rate associated with lower unemployment increases. Figure 10, which presents the relation between changes in employment rates and changes in short-time work take-up rate leads to a consistent observation: it turns out that the relation between changes in employment rates and changes in short-time work take-up rates is slightly positive.

OLS estimates of equation (1) for the unemployment rate are displayed in Table 1. We estimate the model over two different periods. First, the period 2008-2009. Second, the period 2009, which allows us to evaluate the impact of short-time work at the peak of the recession only. 
Table 1: Short-time work and unemployment rate

\begin{tabular}{lcc}
\hline Dependent variable: & \multicolumn{2}{c}{$\Delta$ Unemployment rate } \\
& $(1)$ & $(2)$ \\
\hline$\Delta$ STW take-up rate & $.382^{* * *}$ & .013 \\
EPL regular & $(.101)$ & $(.129)$ \\
& $-.807^{* * *}$ & $-.888^{* * *}$ \\
EPL collective & $(.160)$ & $(.236)$ \\
& $-.374^{* * *}$ & $-.438^{* *}$ \\
EPL temporary & $(.113)$ & $(.168)$ \\
& $.058^{*}$ & .053 \\
Unemployment benefits & $(.097)$ & $(.149)$ \\
& $.017^{* *}$ & .017 \\
Period & $(.009)$ & $(.013)$ \\
Adj. $\mathrm{R}^{2}$ & $2008-2009$ & 2009 \\
Observations & .166 & .133 \\
\hline
\end{tabular}

Note: $\Delta$ Unemployment (resp. STW take-up) rate stands for the difference between the unemployment (resp. shorttime work take-up) rate and its average over the year 2007. All other variables are in level. OLS estimates of Equation (1) for the unemployment rate. ${ }^{* * *}$ statistically significant at the $1 \%$ level, ${ }^{* *}$ at the $5 \%$ level, * at the $10 \%$ level. Standard deviations in brackets.

Column 1 shows that the coefficient associated with the short-time work take-up rate is positive and significant when the estimations cover the period 2008-2009. This positive sign is likely to reflect the endogeneity of short-time work, which necessarily increases with unemployment. This effect should be stronger in the beginning of the recession, when unemployment increases strongly. This interpretation is consistent with the results displayed in column 2, where the coefficient associated with the short-time work take-up rate is not anymore significantly different from zero. Table 1 also shows that changes in the unemployment rate are strongly associated with the OECD indexes of employment protection legislation. More stringent regulation of regular jobs and of collective dismissals is associated with lower increases in unemployment rates. Strikingly, stronger regulation of temporary jobs is not related with change in unemployment.

The OLS estimation of equation (1) when the dependent variable is the employment rate is presented in Table 2 . The coefficient associated with short-time work take-up is not significantly different from zero. Overall, these results do not allow us to find any significant positive relation between the spread of short-time work programs and employment.

However, it should be stressed that the variable $\Delta S T W_{c t}$, standing for short-time take-up rates, is likely to be correlated with the error term $\Delta \varepsilon_{c t}$ in equation (1). There are at least two reasons for this. First, as just explained, the rules of short-time work schemes imply that take-up rates 
increase when economic conditions deteriorate and thus when unemployment raises. Second, we saw above that several governments introduced short-time work programs in the recent recession in order to fight unemployment, while other governments eased the entry into these programs when they were already in place before the downturn. Therefore, countries that had stronger adverse shocks, corresponding to larger $\Delta \varepsilon_{c t}$, could also have larger changes in the regulation of short-time work programs. Accordingly, it is important to instrument short-time take-up rates, i.e. to find variables correlated with short-time take-up rates from 2008, but not correlated with the error term $\Delta \varepsilon_{c t}$. Our instrumental variables belong to the set of parameters which describe the features of short-time work programs before the entry into the recession, i.e. in 2007. This choice is made for two reasons. First, it is likely that the take-up rates have been stronger during the recession in countries where short-time work programs existed or were more generous before the recession, because it takes time to adapt the regulations and to implement short-time work programs. Second, it is likely that the features of short-time work arrangements before the entry into the recession are not correlated with the error term $\Delta \varepsilon_{c t}$ which is related to changes in unemployment during the recession. This is our identifying assumption. ${ }^{1}$

Table 2: Short-time work and employment rate

\begin{tabular}{lcc}
\hline Dependent variable: & \multicolumn{2}{c}{$\Delta$ Employment rate } \\
& $(1)$ & $(2)$ \\
\hline$\Delta$ STW take-up rate & -.083 & .229 \\
& $(.108)$ & $(.141)$ \\
EPL regular & $.694 * * *$ & $.822^{* * *}$ \\
& $(.171)$ & $(.257)$ \\
EPL collective & $.374 * * *$ & $.435^{* *}$ \\
& $(.121)$ & $(.183)$ \\
EPL temporary & $.217^{* *}$ & $.336^{* *}$ \\
& $(.104)$ & $(.162)$ \\
Unemployment benefits & $-.026^{* * *}$ & $-.032^{* *}$ \\
& $(.009)$ & $(.014)$ \\
Period & $2008-2009$ & 2009 \\
Adj. $\mathrm{R}^{2}$ & .143 & .252 \\
Observations & 200 & 100 \\
\hline
\end{tabular}

Note: $\Delta$ Employment (resp. STW take-up) rate stands for the difference between the employment (resp. short-time work take-up) rate and its average over the year 2007. All other variables are in level. OLS estimates of Equation (1) for the employment rate. *** statistically significant at the $1 \%$ level, ** at the $5 \%$ level, * at the $10 \%$ level. Standard deviations in brackets.

Table 3 presents the result of the IV estimates for the period 2008-2009 and for the year 2009 only. The short-time work take-up rate from 2008Q1 is instrumented with the permissible

\footnotetext{
${ }^{1}$ It should be noticed that this identification strategy does not allow us to have time varying instruments. 27
} 
reductions in weekly working hours which can be compensated before 2008 and the short-time work take-up rate in 2007. These instruments allow us to account for the generosity of short-time work programs and their potential adaptability to economic fluctuations before the recession. With these instruments, the assumption that short-time work is exogenous in equation (1), when unemployment is the dependent variable, is rejected at a zero percent level of significance for the period 2008-2009 as shown in Table 3, column 1. The instruments pass the Sargan overidentification test. Table 3, column 1, shows that the coefficient associated with unemployment is strongly significant at the five percent level and large: it is not statistically different from 1 in absolute value. Column 2 shows that this coefficient has the same magnitude and is significant at one percent level when the estimates cover the year 2009 only. As a comparison with the OLS method, this coefficient was either positive or not significantly different from zero, depending on the period. As we stressed before, such results might reflect an endogeneity bias which is treated with the IV methods that yields stable results. ${ }^{1}$ It is also worth noting that regular employment protection limits unemployment hikes while temporary job protection is associated with larger increases in unemployment.

Table 3: Short-time work, unemployment rate and employment rate

\begin{tabular}{lcccc}
\hline Dependent variable: & \multicolumn{2}{c}{$\Delta$ Unemployment } & \multicolumn{2}{c}{$\Delta$ Employment } \\
& $(1)$ & $(2)$ & $(3)$ & $(4)$ \\
\hline$\Delta$ STW take-up rate & $-1.24^{* *}$ & $-1.236^{* * *}$ & $1.142^{* *}$ & $.919^{* *}$ \\
& $(.638)$ & $(.450)$ & $(.561)$ & $(.389)$ \\
EPL regular & $-.782^{* * *}$ & $-.829 * * *$ & $.676^{* * *}$ & $.789^{* * *}$ \\
EPL collective & $(.247)$ & $(.323)$ & $(.217)$ & $(.279)$ \\
EPL temporary & -.182 & -.195 & .236 & .301 \\
& $(.188)$ & $(243)$ & $(.166)$ & $(.210)$ \\
Unemployment benefits & $.426^{* *}$ & $.573 * *$ & -.047 & .049 \\
Period & $(.200)$ & $(.267)$ & $(.176)$ & $(.231)$ \\
Wu Hausman test & .022 & .023 & $-.029 * *$ & $-.035^{* *}$ \\
Sargan test & $(.013)$ & $(.017)$ & $(.012)$ & $(.015)$ \\
Observations & $2008-2009$ & 2009 & $2008-2009$ & 2009 \\
\hline
\end{tabular}

Note: $\Delta$ Employment (resp. unemployment, STW take-up) rate stands for the difference between the employment (resp. unemployment, short-time work take-up) rate and its average over the year 2007. All other variables are in level. IV estimates (2SLS). ${ }^{* * *}$ statistically significant at the $1 \%$ level, ** at the $5 \%$ level, * at the $10 \%$ level. Standard deviations in brackets.

\footnotetext{
${ }^{1}$ We present the estimates with 2 stages least squares. Estimations with the GMM method yield similar results. 28
} 
The results for employment are presented in Column 3 and 4. Independently of the period considered, they are consistent with those obtained with the unemployment rate: the coefficient associated with short-time work take-up is not statistically different from one at the $5 \%$ level confidence rate. Moreover, regular employment protection has a positive impact on employment during the crisis.

Table 4: Short-time work, permanent employment rate and temporary employment rate

\begin{tabular}{lcccc}
\hline Dependent variable: & \multicolumn{2}{c}{$\Delta$ Permanent jobs } & \multicolumn{2}{c}{$\Delta$ Temporary jobs } \\
& $(1)$ & $(2)$ & $(3)$ & $(4)$ \\
\hline$\Delta$ STW take-up rate & $.795^{*}$ & $.811^{* *}$ & -.095 & .122 \\
& $(.416)$ & $(.335)$ & $(.082)$ & $(.091)$ \\
EPL regular & $.347^{* *}$ & .268 & $.360^{* * *}$ & -.219 \\
EPL collective & $(161)$ & $(.241)$ & $(.129)$ & $(.166)$ \\
EPL temporary & .070 & -.024 & $.171 *$ & .007 \\
Unemployment benefits & $(.123)$ & $(.181)$ & $(.091)$ & $(.118)$ \\
Period & -.106 & -.075 & .086 & .097 \\
Adj. R ${ }^{2}$ & $(.131)$ & $(.199)$ & $(.078)$ & $(.105)$ \\
Wu Hausman test & $-.021^{* *}$ & $-.027 * *$ & $-.019 * * *$ & -.005 \\
Sargan test & $(.009)$ & $(.013)$ & $(.007)$ & $(.009)$ \\
Observations & $2008-2009$ & 2009 & $2008-2009$ & 2009 \\
\hline
\end{tabular}

Note: $\Delta$ Permanent jobs (resp. temporary jobs, STW take-up) stands for the difference between the permanent jobs (resp. temporary, short-time work take-up) rate and its average over the year 2007. All other variables are in level. Permanent jobs: IV estimates (2SLS). Temporary jobs: OLS estimates. ${ }^{* * *}$ statistically significant at the $1 \%$ level, ** at the $5 \%$ level, * at the $10 \%$ level. Standard deviations in brackets.

Table 4 presents the results of the estimation of equation (1) for permanent and temporary jobs. The same set of instruments as before is selected. With these instruments, the assumption that short-time work is exogenous in equation (1), where permanent employment is the dependent variable, is rejected at the $1 \%$ level of significance as shown by the p-value of the Wu Hausman test in Columns 1 and 2 of table 4. Moreover, the instruments pass the Sargan over-identification test. However, the assumption of exogeneity of short-time work is not rejected when temporary employment is the dependent variable. Accordingly, we present the results of OLS estimation when the dependent variable is the rate of temporary employment. ${ }^{1}$ Table 4 shows that the

\footnotetext{
${ }^{1}$ 2SLS estimation yields the same coefficient associated with short-time work, which is not significantly different from zero, as the OLS estimation presented in Table 4. 
coefficient associated with short-time work is close to one for permanent employment, but not significantly different from zero for temporary jobs. This suggests that short-time work is mainly beneficial to permanent workers. ${ }^{1}$

\section{CONCLUSION}

Recent empirical studies suggest that short-time work programs have been quite successful in the recent downturn in preserving jobs and in keeping unemployment down. Our paper confirms this finding, for permanent workers who have benefited more from short-time compensation programs than temporary workers. All in all, it seems that short-time work programs used in the recent downturn had significant beneficial effects. This suggests that countries which do not have short-time compensation programs could benefit from their introduction.

However, special attention should be devoted to the design of these programs. Empirical evidence indicates that short-time work programs had beneficial effects in the downturn. But their impact in the recovery period is not documented yet. More time is needed. Short-time work programs can induce inefficient reductions in working hours. They can also inefficiently lower the reallocation of jobs toward more productive jobs. In order to limit these negative effects of short-time work, which may become costly in the long run, two features should be built into their design. First, it is worth introducing experience-rating, which implies that social contributions paid by employers to finance unemployment insurance depend on the costs induced by their participation in short-time work programs. Longer participation in the program should yield higher contribution rates. Second, it is important to commit to stable rules, which may be designed under normal economic conditions - and not during recessions - in order to avoid that in turbulent periods pressure groups require excessively generous schemes, which can be difficult to turn off later on. Indeed, persistently high take-up rates can be costly for the society as a whole and detrimental to some categories of workers non-eligible to short-time compensation programs.

As a final warning, it should be stressed that much remains to be known about the impact of short-time work. There are very few empirical studies devoted to this issue. Empirical evidence about the impact of short-time work in the recent recession is built on macroeconomic data.

${ }^{1}$ The same finding is obtained by Hijzen and Venn (2010). 
Macroeconomic evaluations have the advantage to identify a net global impact or short-time work, including all types of potential effects. But the conclusions of macroeconomic evaluations are necessarily drawn from a relatively small set of observations, which limits the ability to finely identify the impact of programs. Larger sets of observations collected at the firm-level would be needed to confirm these conclusions. As such, controlled experiments would be valuable to avoid the selection bias that could undermine this type of research.

\section{REFERENCES}

Abraham, K. and Houseman, S. (1994), "Does Employment Protection Inhibit Labor Market Flexibility? Lessons from Germany, France, and Belgium", in R. Blank (ed.), Social Protection versus Economic Flexibility: Is There a Trade-Off?, University of Chicago Press, Chicago, pp. 59-94.

Alesina, A., Algan, Y. Cahuc, P. and Giuliano, P. (2010) Family Values and the Regulation of Labor, NBER working paper $n^{\circ} 15747$.

Arpaia, A., Curci, N., Meyermans, E., Peschner, J. and Pierini, F. (2010), "Short-time working arrangements as response to cyclical fluctuations", European Economy Occasional Paper No. 64. European Commission.

Berkeley Planning Associates and Mathematica Policy Research, Inc. (1997), Evaluation of ShortTime Compensation Programs: Final Report, Unemployment Insurance Occasional Paper No. 97-3, US Department of Labor, Employment and Training Administration, Washington.

Blanchard, O. and Tirole, J. (2007) The Optimal Design of Unemployment Insurance and Employment Protection: A First Pass, Journal of the European Economic Association, vol. 6(1), 45-77.

Blanchard, O. and Wolfers, J. (2000), The Role of Shocks and Institutions in the Rise of European Unemployment, Economic Journal, 116(510), 1-33.

Burdett, K. and Wright, R. (1989), Unemployment insurance and Short-Term Compensation: The Effects of Layoffs, Hours per Worker, and Wages", The Journal of Political Economy, Vol. $97(6), 1479-1496$. 
Cahuc, P. and Zylberberg, A. (2008), Optimum Taxation and Layoff Taxes, Journal of Public Economics, 92 (10-11), 2003-2019.

Calavrezo, O., Duhautois, R., and Walkoviak, E. (2009a), Chômage partiel et licenciements économiques, Connaissance de l'emploi, Centre d'études de l'emploi, No. 63, March..

Calavrezo, O., Duhautois, R., and Walkoviak, E. (2009b), Short-Time Compensation and Establishment Survival: An Empirical Analysis with French Data, Comparative Analysis of Enterprise Data (CAED) Conference, 2-4 October, Tokyo, Japan.

Deeke, A., (2005): Kurzarbeit als Instrument betrieblicher Flexibilität. Ergebnisse aus dem IABBetriebspanel 2003. IAB Forschungsbericht 12/2005. Nürnberg: IAB.

Feldstein, M. (1976), Temporary layoffs and the theory of unemployment, Journal of Political Economy 84,937-957.

Hijzen, A. and Venn, D. (2010), The role of short-time work schemes during the 2008-09 recession, OECD working paper, forthcoming.

Holmlund, B. and Fredriksson, P. (2006), Improving Incentives in Unemployment Insurance: A Review of Recent Research, Journal of Economic Surveys, vol 20, No 3.

Janiak. D., and Wasmer, E. (2010), Local social capital and geographical mobility, forthcoming, Journal of Urban Economics.

Kerachsky, S., Nicholson, W., Cavin, E. and Hershey, A. (1986), An Evaluation of Short-Time Compensation Programs Occasional Paper 86-4. Washington, D.C.: U.S. Department of Labor and Mathematica Policy Research.

OECD (2010) Employment outlook, OECD, Paris.

Van Audenrode, M. A. (1994), Short-Time Compensation, Job Security, and Employment Contracts: Evidence from Selected OECD Countries, Journal of Political Economy, Vol. 102, No. 1. (Feb.), pp. 76-102.

Vroman, W. and Brusentsev, V. (2009), Short-Time Compensation as a Policy to Stabilize Employment, University of Delaware, November 2009, mimeo http://www.urban.org/uploadedpdf/411983_stabilize_employment.pdf 
Walsh, S., London, R., McCanne, D., Needels, K., Nicholson, W. and Kerachsky, S. (2007), Evaluation of Short-Time Compensation Programs, Berkeley Planning Associates / Mathematica Policy Research Inc., Final Report for the U.S. Department of Labor, March 2007. 